\title{
Erratum to: The Usability of Asset Index as an Indicator of Household Economic Status in Turkey: Comparison with Expenditure and Income Data
}

\section{Baris Ucar}

Published online: 12 July 2014

(C) Springer Science+Business Media Dordrecht 2014

\section{Erratum to: Soc Indic Res \\ DOI 10.1007/s11205-014-0670-2}

The first line of the Abstract the word "tolls" should be corrected with "tools".

The sentence presently in the abstract:

Information on expenditure and income are the most widely used tolls for differentiating economic status of households.

Should read:

Information on expenditure and income are the most widely used tools for differentiating economic status of households.

The online version of the original article can be found under doi:10.1007/s11205-014-0670-2.

B. Ucar $(\bowtie)$

Hacettepe Universitesi Nufus Etutleri Enstitusu, Merkez Kampusu D Blok Kat:5 Sihhiye,

06100 Ankara, Turkey

e-mail: ucarbaris1@ hotmail.com 